than the production of antibiotics, where bacteria excrete the product. Nevertheless, it should prove far less costly than the current methods of extracting porcine and beef insulin. The cost of human insulin to the consumer, however, will depend on its penetration into the market and competition from other companies. When costs will come down is still uncertain, especially since Lilly cannot even say yet when it will be in a position to start commercial production.

Judy Redfearn

\section{Environmental protection}

\section{Bulgaria ahead}

Bulgaria is to spend more than 1,000 million lev ( $£ 500$ million) on environmental protection during the next five years, President Todor Zhivkov announced recently. He was addressing a meeting held to celebrate the 80th anniversary of the Bulgarian National Agricultural Union.

In Bulgaria, President Zhivkov said, the Constitution makes environmental protection a nationwide matter, dealt with by specially created bodies at all levels of state management. Ecological problems are a compulsory subject in higher educational establishments and throughout the educational system. Special organizations have been set up to deal with erosion and bring reclaimed or neglected soil back into use. Bulgaria, he said, is a world leader in reafforestation, planting 400-500 decares per year.

Zhivkov unequivocally rejected the view of "bourgeois ideologists" who maintain that the violation of the established ecological balance is the result of the modern scientific-technological revolution. On the contrary, he said, this revolution is essentially "our greatest ally in harmonizing relations between society and nature". Although the published data on natural resources are so "very alarming", Zhivkov reiterated that "being aware of the danger is a signal for action, not a cause for pessimism".

Bulgaria is not rich in natural resources, and before the Second World War it was the most backward but one of the European countries (Albania ranked last). Now, however, Zhivkov claimed his country is a "developed industrial agrarian country", with an agriculture capable of feeding "one and a half Bulgarias" and a target of "two Bulgarias" in 1985. Referring to his African tour of two years ago, Zhivkov suggested that if Nigeria, Angola, Ethiopia and Mozambique could apply Bulgarian-type organization and technology to their agriculture, they too would be producing surpluses. Ethiopia, in particular, he said, has especially good soil which could not only support the present population but also "feed a neighbouring state".

Vera Rich

\title{
One journal disowns plagiarism
}

SIR - Your recent article "An Outbreak of Piracy in the Literature" makes it apparent that the Japanese Journal of Medical Science and Biology (JJMSB) was a victim of an outbreak of paper piracy by a person called Dr A. Alsabti. I am writing this letter on behalf of the Editorial Board of $J J M S B$ to make our position clear. Our unfortunate experience shows how difficult it is to be aware of dastardly and minutely planned piracy of papers.

We first received this manuscript entitled "Effect of Platinum Compounds on Murine Lymphocyte Mitogenesis" on 20 November 1978 from the stated address Department of Developmental Therapeutics, M.D. Anderson Hospital and Tumor Institute, University of Texas System Cancer Center. After careful reviewing, the manuscript was sent back on 25 December 1978 with referees' comments to Dr Alsabti at his changed address (7520 Brompton Blvd, No. 736, Houston, Texas 77025). The revised manuscript was received in our editorial office on 16 January 1979 , but it was still not satisfactory for publication and it was again sent back to him on 12 February. The final revision was received on $2 \mathrm{March}$, and the editorial board accepted it for publication on 12 April 1979. On 11 May 1979 , a galley proof was sent to him and he asked us to send any further correspondence to his new address - 7511 Teal Run, Houston, Texas 77071. On 11 June 1979 the paper was finally published in the April issue of our journal (Japan. J. med. Sci. Biol. 32, 53-65, 1979).

The editing of Dr Alsabti's paper therefore followed quite a normal course. However, it may be important to add here that we received three other manuscripts from him at around the same time. These were:

(1) Effects of tumor cell culture supernatants from various tumor cell line and normal tissues on macrophages.

(2) Tumor dormancy established in $\mathrm{DBA} / 2$ mice with P815Y mastocytoma cell lines.

(3) Tumor dormant state established in DBA $/ 2$ mice by sinecomitant immunization and challenge with lymphoma cells: Role of endogenous viruses in its mechanism.

All these papers were rejected.

Almost one year later we received a shocking letter from Dr D. Wierda of the Chemical Industry Institute of Toxicology, North Carolina, USA. His letter told us an almost unbelievable fact, that the paper entitled "Suppression of Spleen Lymphocyte Mitogenesis in Mice Injected with Platinum Compounds" contributed by himself and Dr T.L. Pazdernik to the European Journal of Cancer (15, 1013-1023; 1979) is identical to Dr Alsabti's "Effect of Platinum Compounds on Murine Lymphocyte Mitogenesis", published in our journal. Dr Wierda enclosed copies of proofs demonstrating the authenticity of his work and suspected that their manuscript was probably pirated during the process of review for the European Journal of Cancer. He added that their manuscript was received on 10 October 1978, accepted for publication on 5 January 1979 and published in the August 1979 issue of European Journal of Cancer.

In urgent response to Dr Wierda's letter I wrote to Dr Alsabti on 9 June 1980 to ask for an explanation of this unusual situation, specifying a time limit of 15 July, 1980. This letter was sent to his last corresponding address. I also asked Dr Freireich, head of the Department of Developmental Therapeutics, M.D. Anderson Hospital and Tumor Institute, to forward my letter to Dr Alsabti.

On 30 June 1980 Dr Freireich wrote to tell me that he could not forward my letter to Dr Alsabti as his address was unknown. However, he proved that Dr Alsabti had never conducted any scientific research worthy of publication, either in the laboratory or clinic, during his 7 months' stay in his department, and suggested further that his large number of publications are all either outright plagiarisms or were totally imaginary.

We have so far received no reply from $\mathrm{Dr}$ Alsabti, although the deadline we gave him has already expired. Furthermore, Dr Wierda notified me on 21 July of the article "Jordanian Denies He Pirated Papers" (in the 11 July issue of Science) in which Dr Alsabti claimed that he had not published the paper in $J J M S B$. We therefore decided to retract Dr Alsabti's paper to protect the characters of Drs D. Wierda and T.L. Pazdernik. Japanese Journal of Medical Science and Biology hereby announces retraction of his paper from our journal. Our "Retraction Notice" will appear in the coming August issue of Japan. J. med. Sci. Biol. 33 (4), 1980 as follows:

The Editorial Board of the Japanese Journal of Medical Sciences and Biology here announces retraction of the following paper from the Journal:

"Effect of Platinum Compounds on Murine Lymphocyte Mitogenesis" by E.A.K.

Alsabti, O.N. Ghalib, and M.H. Salem.

Japan. J. med. Sci. Biol. 32(2), 53-65, 1979.

Judging from several lines of evidence (1-5), this work must have been authentically carried out by Drs D. Wierda, and T.L. Pazdernik, whose paper was almost simultaneously published in the Eur. J. Cancer (15 (8), 1013-1023, 1979) under the title of "Suppression of Spleen Lymphocyte Mitogenesis in Mice Injected with Platinum Compounds".

1. Letters from Drs D. Wierda \& T.L. Pazdernik

2. Correspondence to the Head of Department of Developmental Therapeutics, M.D. Anderson Hospital and Tumor Institute, the University of Texas System Cancer Center, with which Dr. Alsabti was affiliated.

3. Nature $285,429-430$ (1980).

4. Science 208, 1438-1440 (1980)

Science 209, 249 (1980).

Akira Shishido National Institute of Health, Tokyo, Japan. 